\title{
IOWA Unemployment Insurance Claimants: A Comparison between $\alpha$-Sutte Indicator and Other Forecasting Methods
}

Ansari Saleh Ahmar ${ }^{1}$, Abdul Rahman ${ }^{2}$, Heri Nurdiyanto ${ }^{3}$, Darmawan Napitupulu ${ }^{4}$, Dahlan Abdullah $^{5}$, Muhammad Ikhsan Setiawan ${ }^{6}$, Janner Simarmata ${ }^{7}$, Rahmat Hidayat ${ }^{8}$, Wahyudin Albra $^{9}$, Robbi Rahim ${ }^{10}$

\{ansarisaleh@unm.ac.id, abdul.rahman@unm.ac.id, herinurdiyanto@gmail.com, darwan.na70@gmail.com, dahlan@unimal.ac.id, ikhsan.setiawan@narotama.ac.id, rahmat@ polinpdg.ac.id,wahyuddin@unimal.ac.id, usurobbi85@zoho.com \}

Department of Statistics, Universitas Negeri Makassar, Makassar, Indonesia ${ }^{1}$ Department of Mathematics, Universitas Negeri Makassar, Makassar, Indonesia ${ }^{2}$ Department of Informatics, STMIK Dharma Wacana, Metro Lampung, Indonesia ${ }^{3}$

Research Center for Quality System and Testing Technology, Indonesian Institute of Sciences, Indonesia ${ }^{4}$

Department Informatics, Universitas Malikussaleh, Lhokseumawe, Indonesia ${ }^{5}$ Department of Civil Engineering, Narotama University, Indonesia ${ }^{6}$ Universitas Negeri Medan, Medan, Indonesia ${ }^{7}$

Department of Information Technology, Politeknik Negeri Padang, Indonesia ${ }^{8}$ Department of Management, Universitas Malikussaleh, Aceh, Indonesia ${ }^{9}$ Sekolah Tinggi Ilmu Manajemen Sukma, Medan, Indonesia ${ }^{10}$

\begin{abstract}
This UI program if it isn't managed well so that can affect the insurance company performance and can make the company loss. One of the ways to know the development of this insurance claim for each month is that by forecasting the people who are interested in this insurance. The aim of this study is forecasting unemployment insurance claimants in IOWA, USA. This research uses ARIMA, NNETAR, Robus Exponensial Smooting, Theta Model, and $\alpha$-Sutte Indicator forecasting method. The use of this method is intended to be compared the level of accuracy from various forecasting methods. To see the quality of the forecast, so that it will be used a comparison based on MSE score. The lower MSE Score, the better accuracy level that they have. The result of this study is $\alpha$-Sutte Indicator is more appropriate in forecasting data unemployment insurance claim in IOWA. The accuracy level of $\alpha$-Sutte Indicator is better if it is compared to any other methods.
\end{abstract}

Keywords: Forecasting, unemployment insurance claimants, $\alpha$-Sutte Indicator, ARIMA

ICASI 2018, April 23-24, Medan, Indonesia

Copyright $\odot 2018$ EAI

ISBN: 978-1-63190-162-1 


\section{Introduction}

The thing that becomes the main problem of a country is the high level of unemployment or no jobs. This problem makes every country feel confused to find the solution. The higher unemployment is caused by lots of age productive citizens who don't have a job. This is caused by the inappropriate competence that they have with the necessary competence. Besides, the high number of dropout becomes one of the causes of the high number of employment in a country.

The unemployment becomes the common matter from almost every area. The workers are labors from a company that have outsourcing status can possibly be fired because there is no clear working contract between the company and the labor. Outsourcing labor can also be fired at any time and of course different from permanent employee. Outsourcing labor doesn't have the right to receive pension allowance and other allowances.

According to Iqbal and Dad [1], Offshore outsourcing is a phenomenon that has been going for a long time and many multinational companies use this strategy to reduce operational costs. Outsourcing is a process of handover of one or more business process to outside vendors that are provided by the third parties to run the business process, for instance at cleaning service and security.

In big cities, most of the workers pick job insurance. In other words, this worker insurances himself/herself so that later on if he/she doesn't work so that they can claim the insurance. In big cities for example in IOWA United States, the worker who resigns from the job and has the ability to work, they can get temporary salary through Unemployment Insurance (UI) program. This UI program will give job seekers a payment to help them in covering living expenses temporarily while looking for a new job.

This UI program if it isn't managed well so that can affect the insurance company performance and can make the company loss. One of the ways to know the development of this insurance claim for each month is that by forecasting the people who are interested in this insurance. By the existence of the data forecasting result, the insurance company can form a plan and make a decision towards the issue in the future. The method that is often used in forecasting i.e. ARIMA [2-5], ARIMA-AO [6], Holt-Winters [3], Neural Network Time Series [7, 8], $\alpha$-Sutte Indicator [9], and other methods [10].

The forecasting about unemployment insurance has been researched by other academicians, for instance: Mandy conducts a research about unemployment insurance forecast towards Tennessee case study [11], Barnichon conducts a research about The Ins and Outs of forecasting unemployment based on labor force flows [12], and the last one by Huang who discusses about forecasting the US unemployment rate with job openings index, this research uses ARIMA, ARIMAX, and VAR method in its forecasting process [13].

\section{a-Sutte Indicator}

$\alpha$-Sutte Indicator is a new forecasting method that is currently developed by using 4 previous data. The uses of previous data is intended to accommodate the unstable data movement. Thus, the formula of $\alpha$-Sutte Indicator mathematically is as follows [4, 14]: 


$$
a_{t}=\frac{\alpha\left(\frac{\Delta x}{\frac{\alpha+\delta}{2}}\right)+\beta\left(\frac{\frac{\Delta y}{\beta+\alpha}}{2}\right)+\gamma\left(\frac{\Delta z}{\frac{\gamma+\beta}{2}}\right)}{3}
$$

where:

$$
\begin{aligned}
& \delta=a_{t-4} \\
& \alpha=a_{t-3} \\
& \beta=a_{t-2} \\
& \gamma=a_{t-1} \\
& \Delta x=\alpha-\delta=a_{t-3}-a_{t-4} \\
& \Delta y=\beta-\alpha=a_{t-2}-a_{t-3} \\
& \Delta z=\gamma-\beta=a_{t-1}-a_{t-2} \\
& a_{t}=\text { data at } t \text { time } \\
& a_{t-k}=\text { data at }(t-k) \text { time }
\end{aligned}
$$

\section{Methods}

This research uses ARIMA, NNETAR, Robus Exponensial Smooting, Theta Model, and $\alpha$-Sutte Indicator forecasting method. The use of this method is intended to be compared the level of accuracy from various forecasting methods. To see the quality of the forecast, so that it will be used a comparison based on MSE score. The lower MSE Score, the better accuracy level that they have.

This research will use dataset unemployment insurance claim in IOWA, USA. This dataset is acquired from the website that is provided by Iowa Workforce Development - Labor Market Information Division [15]. This dataset consists of 221 data i.e. January 2000 - May 2018. In the process of data forecasting so that $\mathrm{R}$ Package will be used that is sutteForecastR and RcmdrPlugin.sutteForecastR [16-18].

\section{Result and Discussion}

In conducting the forecast, the first step that has to be done is by doing a data plotting to see the data characteristics. 


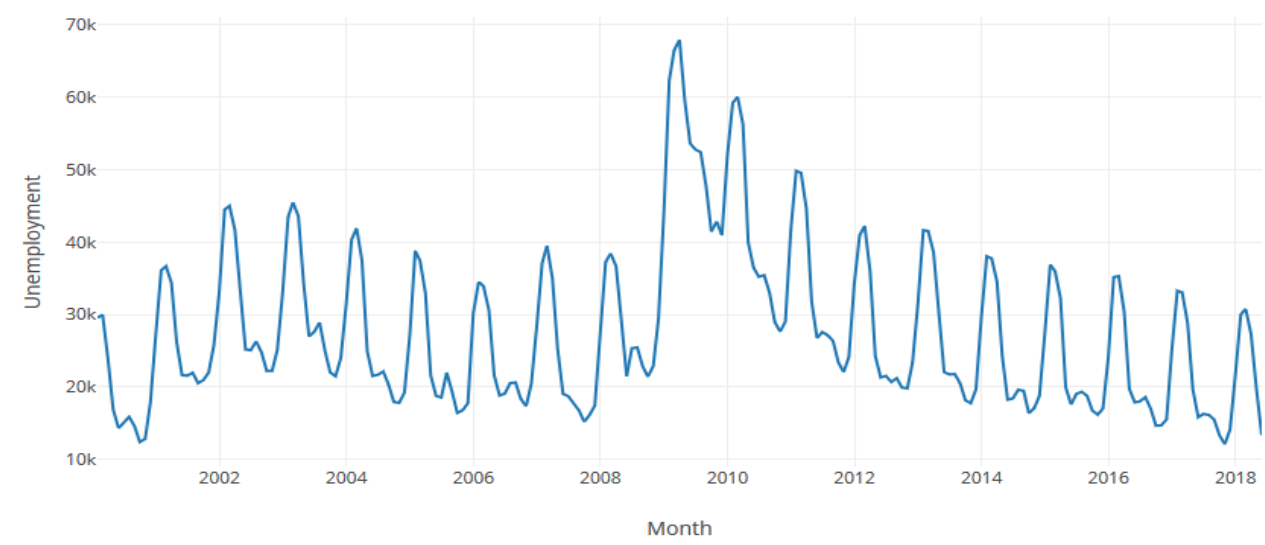

Fig. 1. Plotting data unemployment insurance claim in IOWA

In figure 1 , it can be seen that the data is unstable (stationer) in its average or even its variance. In addition, it can be seen that the sudden increase of the unemployment data happens around 2009 - 2010.

After conducting the data plotting, the next step is data forecasting by using $\mathrm{R}$ Package i.e. sutteForecastR help. This package is $\mathrm{R}$ Package from $\alpha$-Sutte Indicator method. sutteForecastR is $\mathrm{R}$ package which compare several forecasting methods i.e., $\alpha$-Sutte Indicator, ARIMA, Holt-Winters, NNETAR, Robust Exponential Smooting, and Theta Model. Thus, the result is as follows.

$>$ library(sutteForecastR)

$>$ alpha.sutte(data3.ts)

\$Tes_Data

[1] 14144217653001330802272941995713372

\$Forecast_AlphaSutte

[1] 10841.0913817 .7325177 .7937009 .9037335 .1729648 .9817058 .78

\$Forecast_AutoARIMA

Point Forecast Lo 80 Hi 80 Lo 95 Hi 95

$215 \quad 14602.7510406 .42618799 .088185 .024221020 .48$

$216 \quad 19813.9412239 .41427388 .488229 .699731398 .19$

$217 \quad 24126.9313493 .65734760 .217864 .740540389 .12$

$218 \quad 24966.1012269 .50337662 .705548 .329244383 .88$

$219 \quad 23094.99 \quad 9643.22836546 .762522 .293243667 .69$

$220 \quad 21534.68 \quad 7968.24735101 .11 \quad 786.612642282 .74$

$221 \quad 22478.58 \quad 8890.03536067 .131696 .693043260 .47$

\$Forecast_HoltWinters

Point Forecast Lo 80 Hi $80 \quad$ Lo $95 \quad$ Hi 95

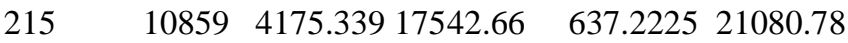

$216 \quad 9607 \quad-5338.12024552 .12-13249.589432463 .59$ 
$217 \quad 8355-16652.97033362 .97 \quad-29891.3893 \quad 46601.39$

$\begin{array}{llllll}218 & 7103 & -29504.919 & 43710.92 & -48883.9812 & 63089.98\end{array}$

$219 \quad 5851-43716.35755418 .36-69955.7309 \quad 81657.73$

$220 \quad 4599-59159.06368357 .06-92910.5428102108 .54$

$221 \quad 3347-75735.14482429 .14-117598.7026124292 .70$

\$Forecast_NNETAR

Point Forecast

$215 \quad 14276.26$

$216 \quad 23856.43$

$217 \quad 32637.93$

$218 \quad 34066.50$

$219 \quad 31116.34$

$220 \quad 23586.88$

$221 \quad 18517.00$

\$Forecast_Robust_exponential_smoothing

Point Forecast Lo 80 Hi 80 Lo 95 Hi 95

$215 \quad 11251.0678860 .044013642 .097594 .313014907 .82$

$216 \quad 10389.3917111 .139613667 .645375 .738115403 .04$

$217 \quad 9527.7155633 .473413421 .96 \quad 3571.986115483 .44$

$218 \quad 8666.0404304 .977413027 .10 \quad 1996.370415335 .71$

$219 \quad 7804.3643076 .047412532 .68 \quad 573.027615035 .70$

$220 \quad 6942.6891919 .757611965 .62 \quad-739.221514624 .60$

$221 \quad 6081.013 \quad 818.940811343 .09-1966.631914128 .66$

\$Forecast_Theta

Point Forecast Lo 80 Hi 80 Lo 95 Hi 95

$215 \quad 12105.72 \quad 4988.126319223 .31 \quad 1220.30222991 .13$

$\begin{array}{llllll}216 & 12100.31 & 2035.019322165 .60 & -3293.223 & 27493.84\end{array}$

$217 \quad 12094.90-232.305324422 .11-6757.93430947 .74$

$218 \quad 12089.49-2144.620026323 .61-9679.70433858 .69$

$219 \quad 12084.09-3830.057427998 .23-12254.49636422 .67$

$220 \quad 12078.68-5354.334329511 .69-14582.81338740 .17$

$221 \quad 12073.27-6756.490430903 .03-16724.36340870 .90$

\$AutoARIMA

Series: al_mi_10

$\operatorname{ARIMA}(\overline{3}, 0, \overline{3})$ with non-zero mean

Coefficients:

ar1 ar2 ar3 ma1 ma2 ma3 mean

$\begin{array}{llllllll}1.7561 & -1.6458 & 0.7203 & -0.2534 & 0.7853 & 0.2832 & 27674.463\end{array}$

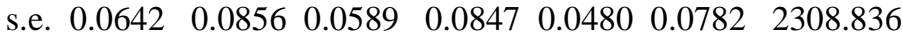

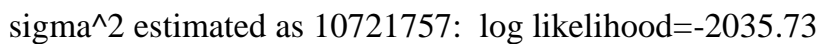

$\mathrm{AIC}=4087.46 \quad \mathrm{AICc}=4088.16 \quad \mathrm{BIC}=4114.38$ 


\section{\$HoltWinters}

Holt-Winters exponential smoothing with trend and without seasonal component.

Call:

HoltWinters $(\mathrm{x}=$ al_mi_10, gamma $=$ FALSE)

Smoothing parameters:

alpha: 1

beta : 1

gamma: FALSE

Coefficients:

$[, 1]$

a 12111

b -1252

\$NNETAR

Series: al_mi_10

Model: NNAR $(13,7)$

Call: nnetar(y = al_mi_10)

Average of 20 networks, each of which is a 13-7-1 network with 106 weights options were - linear output units

sigma^2 estimated as 491972

\$Robust_exponential_smoothing ROBETS(M,A,N)

Call:

$\operatorname{robets}(\mathrm{y}=$ al_mi_10)

Smoothing parameters:

alpha $=0.9956$

beta $=0.0021$

Initial states:

sigma $=0.1833$

$1=25060$

$\mathrm{b}=-1309$

sigma: 0.2253

robAIC robAICc robBIC

4675.355 4675.4124682.087

\$Theta_Model 
Theta

Call:

forecast::ets $(\mathrm{y}=\mathrm{y}$, model $=$ "ANN", opt.crit = "mse")

Smoothing parameters:

alpha $=0.9999$

Initial states:

$1=20421.7235$

sigma: 5553.885

AIC AICc BIC

4842.6344842 .7484852 .732
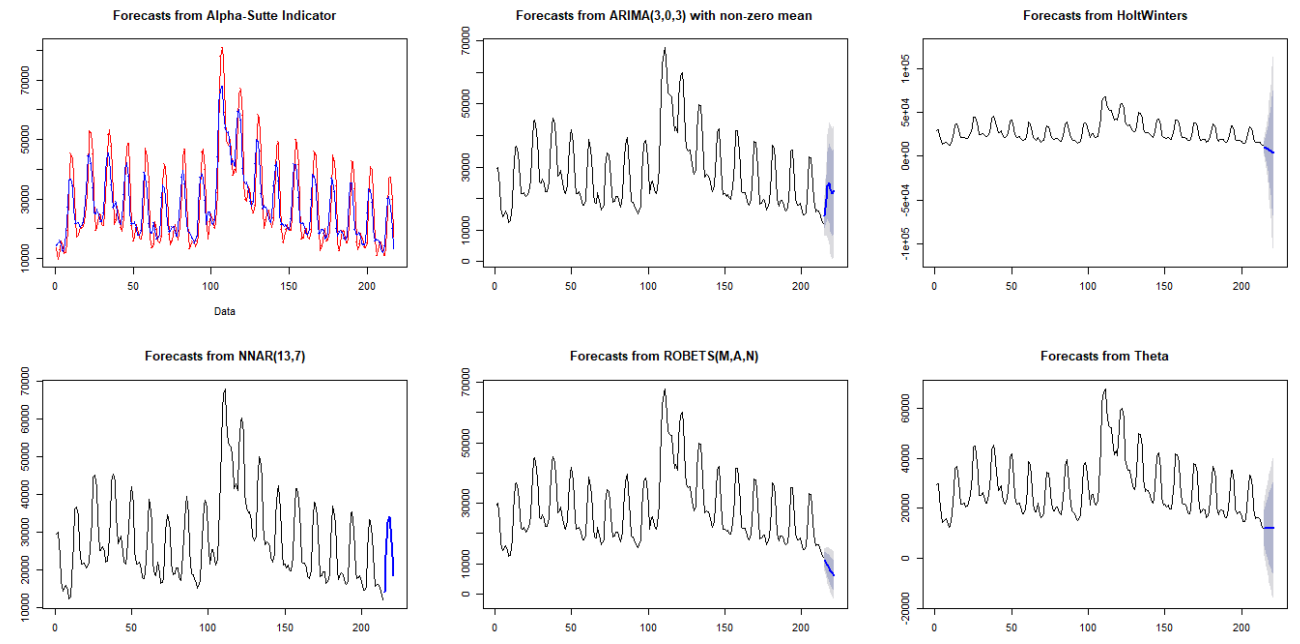

Fig. 2. Output Result of sutteForecastR

From the output result of sutteForecastR, it can be seen that the acquired model for unemployment insurance claim forecasting i.e. $\operatorname{ARIMA}(3,0,3)$ with non-zero mean; HoltWinters $(\alpha=1, \beta=1)$; NNAR(13,7); ROBETS(M,A,N); Theta $(\alpha=0.9999)$. Therefore, the comparison result of accuracy level of this forecasting method is displayed on table 1.

Table 1. The comparison of Forecasting Accuracy Level from Various Forecasting Methods

\begin{tabular}{ll}
\hline Metode & Mean Squared Error (MSE) \\
\hline$\alpha$-Sutte Indicator & 4708563,194 \\
ARIMA $(3,0,3)$ with non-zero mean & 75761678,297 \\
Holt-Winters $(\alpha=1, \beta=1)$ & 250262050,138 \\
NNAR $(13,7)$ & 289303209,136
\end{tabular}




\begin{tabular}{ll}
\hline Metode & Mean Squared Error (MSE) \\
\hline ROBETS(M, A, N) & 220646298,135 \\
Theta $(\alpha=0.9999)$ & 96594696,765 \\
\hline
\end{tabular}

From the table 1 , it can be seen that $\alpha$-Sutte Indicator method has higher accuracy than other methods; this can be seen from the MSE score from MSE and from $\alpha$-Sutte Indicator that is smaller than any other methods. If it is based on accuracy level, the forecasting method that has the best accuracy simultaneously is $\alpha$-Sutte Indicator; $\operatorname{ARIMA}(3,0,3)$ with non-zero mean; Theta $(\alpha=0.9999) ; \operatorname{ROBETS}(\mathrm{M}, \mathrm{A}, \mathrm{N})$; HoltWinters $(\alpha=1, \beta=1)$; $\operatorname{NNAR}(13,7)$. The forecasting result from various forecasting methods can be seen in picture 3 .

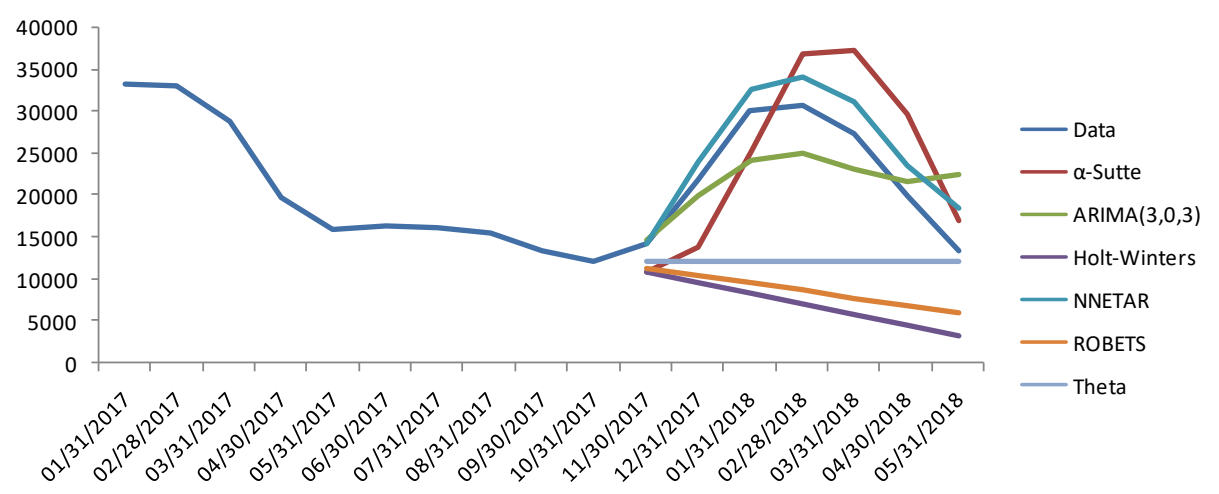

Fig. 3. The Comparison of Forecasting Result from Various Forecasting Methods

\section{Conclusion}

Dataset unemployment insurance claim in IOWA is a dataset that has unpredictable fluctuation level and of course, in forecasting it needs the appropriate method. Based on the result that is acquired by doing the forecasting using various forecasting methods, it is known that $\alpha$-Sutte Indicator is more appropriate in forecasting data unemployment insurance claim in IOWA. The accuracy level of $\alpha$-Sutte Indicator is better if it is compared to any other methods.

\section{References}

[1] Iqbal, Z., Dad, A.M.: Outsourcing: A review of trends, winners \& losers and future directions. Int. J. Bus. Soc. Sci. 4, (2013).

[2] Ahmar, A.S.: A comparison of $\alpha$-Sutte Indicator and ARIMA methods in renewable energy forecasting in Indonesia. Int. J. Eng. Technol. 7, (2018).

[3] Rahman, A., Ahmar, A.S.: Forecasting of primary energy consumption data in the United States: A comparison between ARIMA and Holter-Winters models. In: AIP Conference Proceedings (2017).

[4] Sutiksno, D.U., Ahmar, A.S., Kurniasih, N., Susanto, E., Leiwakabessy, A.:

Forecasting Historical Data of Bitcoin using ARIMA and $\alpha$-Sutte Indicator. J. Phys. Conf. Ser. 1028, 012194 (2018). 
[5] Kurniasih, N., Ahmar, A.S., Hidayat, D.R., Agustin, H., Rizal, E.: Forecasting Infant Mortality Rate for China: A Comparison Between $\alpha$-Sutte Indicator, ARIMA, and Holt-Winters. J. Phys. Conf. Ser. 1028, 012195 (2018).

[6] Ahmar, A.S., Guritno, S., Abdurakhman, Rahman, A., Awi, Alimuddin, Minggi, I., Tiro, M.A., Aidid, M.K., Annas, S., Sutiksno, D.U., Ahmar, D.S., Ahmar, K.H., Ahmar, A.A., Zaki, A., Abdullah, D., Rahim, R., Nurdiyanto, H., Hidayat, R., Napitupulu, D., Simarmata, J., Kurniasih, N., Abdillah, L.A., Pranolo, A., Haviluddin, Albra, W., Arifin, A.N.M.: Modeling Data Containing Outliers using ARIMA Additive Outlier (ARIMA-AO). J. Phys. Conf. Ser. 954, (2018).

[7] Haviluddin, Agus, F., Azhari, M., Ahmar, A.S.: Artificial neural network optimized approach for improving spatial cluster quality of land value zone. Int. J. Eng. Technol. 7, (2018).

[8] Surahman, Viddy, A., Gaffar, A.F.O., Haviluddin, Ahmar, A.S.: Selection of the best supply chain strategy using fuzzy based decision model. Int. J. Eng. Technol. 7, (2018).

[9] Ahmar, A.S., Rahman, A., Mulbar, U.: $\alpha$-Sutte Indicator: a new method for time series forecasting. J. Phys. Conf. Ser. 1040, 012018 (2018).

[10] Ahmar, A.S., Rahman, A., Arifin, A.N.M., Ahmar, A.A.: Predicting movement of stock of "Y" using sutte indicator. Cogent Econ. Financ. 5, (2017).

[11] Mandy, D.M.: Forecasting unemployment insurance trust funds: The case of Tennessee. Int. J. Forecast. 5, 381-391 (1989).

[12] Barnichon, R., Nekarda, C.: The Ins and Outs of Forecasting Unemployment: Using Labor Force Flows to Forecast the Labor Market. Brookings Pap. Econ. Act. 83-132 (2012).

[13] Huang, X.: Forecasting the US Unemployment Rate with Job Openings Index, http://digitalcommons.uri.edu/theses/699, (2015).

[14] Ahmar, A.S.: A Comparison of $\alpha$-Sutte Indicator and ARIMA Methods in Renewable Energy Forecasting in Indonesia. Int. J. Eng. Technol. 7, 20-22 (2018).

[15] State of IOWA: Iowa Unemployment Insurance Claimants by Age, https://data.iowa.gov/Economy/Iowa-Unemployment-Insurance-Claimants-byAge/7uss-66ak.

[16] Ahmar, A.S.: RcmdrPlugin.sutteForecastR: a plugin in Rcmdr for Forecasting Data. J. Phys. Conf. Ser. 1028, 012224 (2018).

[17] Ahmar, A.S.: sutteForecastR: Forecasting Data using Alpha-Sutte Indicator, https://cran.r-project.org/web/packages/sutteForecastR/index.html.

[18] Ahmar, A.S.: RcmdrPlugin. sutteForecastR:'Rcmdr'Plugin for Alpha-Sutte Indicator, https://cran.r-project.org/web/packages/RcmdrPlugin.sutteForecastR/index.html. 